\title{
Phosphorous use efficiency as affected by phosphorous placement methods and maize genotypes in Arsi Neggele, Ethiopia
}

\author{
Eshetayehu Tefera $^{1 *}$ and Heluf Gebrekidan ${ }^{2}$ \\ ${ }^{1}$ Ethiopian Agricultural Transformation Agency (ATA), P. O. Box 110110, Addis Ababa, Ethiopia. \\ ${ }^{2}$ Alemaya University, P.O. box 138, Dire Dawa, Ethiopia.
}

Accepted 17 July, 2017

\begin{abstract}
Placement geometry of phosphorous $(\mathrm{P})$ fertilizer potentially affects plant $\mathrm{P}$ use efficiency. Recognizing the virtual effect of placement methods and maize genotype to $P$ absorption, a field experiment employing a split plot design was conducted in Arsi Neggele, Ethiopia to investigate the relative effect of different P placement methods and maize genotypes on available soil $P$, uptake and apparent recovery of $P$. The values of Bray-II available soil $P$ showed greater variation due to $P$ placement methods than due to maize genotypes. Though inconsistent across all varieties, grain $P$ uptake response was higher for placement between two seeds (PPD) or row drilling (RD) than point placement at a side (PPS), broadcasting (BC) and no $P$ applied plots (NPP) under the local cultivar. It was also higher for PPD than PPS, BC and NPP under the varieties PHB3253 and $\mathrm{A}-511$, and was indifferent under the variety $\mathrm{BH}-540$. Similarly, $\mathrm{P}$ uptakes in plant and stover plant parts were in most cases superior for PPD and RD than the other placement methods. For genotype by $P$ placement interaction, the highest statistical plant and stover $P$ uptakes values were observed for PPD combined with local cultivar. The same PPD method combined with PHB-3253 and A-511 revealed the most and second most efficient grain $\mathrm{P}$ uptakes, respectively. Apparent $\mathrm{P}$ recovery also varied from less than zero to $60 \%$ due to the effects of the two factors and their interaction with substantial soil and plant $P$ nutritional interrelationship.
\end{abstract}

Keywords: Maize genotype, phosphorous placement, phosphorous uptake, soil phosphorous.

*Corresponding author. E-mail: eshett2002@yahoo.com. Tel: 251911101381.

\section{INTRODUCTION}

Prosperous $(\mathrm{P})$ absorption by plants is serious problem due to the fact that the supply of $P$ in most soils is low, the phosphates in soils are not readily available for plant use, and soil $P$ is immobile (Tisdale et al., 1993; Miller and Donhaue, 1995). Right place of application has always been critical in ensuring nutrient efficacy and $P$ efficiency as $P$ is one of the least available and least mobile mineral nutrients in the soil (Robert, 2008). FAO (2016) also debates on imperfectly placed $P$ in the soil due to its nature of reacting with cations to form insoluble compounds. Therefore, determining the proper zone of fertilizer placement, particularly that of phosphorus is important to choose the right analysis or the correct amount of plant nutrients (Kipps, 1981). According to Tisdale et al. (1993), sometimes it is not what is done but how it is done that influences response of crop plants to nutrients; placement can cause marked yield differences. Mesfin (1980) stated, "arbitrary ways of fertilizer application in Ethiopia added to the vagrancy of nature has contributed to its use inefficiency". It is generally assumed that fertilizer placement affects the use efficiency of fertilizer nutrients, level of salt toxicity as well as conveniences of crop management practices. Tisdale et al. (1993) reported that broadcasting soluble phosphate 
results in more $\mathrm{P}$ fixation than banding methods. Mallarino et al. (1999) also reported that band placement methods often increased $P$ uptake more than the broadcast treatment. In relation to soil $\mathrm{P}$ value, Olson and Sander (1992) reported that maize response was quite unlikely when the soil test values are greater than $15 \mathrm{mg}$ $\mathrm{P} / \mathrm{kg}$. Taylor et al. (1998) reported strong relationship between extractable soil $\mathrm{P}$ content and tissue concentration with correlation values of $0.77^{\star *}$ (Mehlich-I) and $0.74^{\star *}$ (Bray P-I) for Sudan grass. In relation to genotype, Sumio and Barber (1993) described that plant varieties vary in the amount of nutrients they absorb from the soil. Nutrient uptake and nutrient concentration of different plant parts also showed significant variation due to differences in hybrids and/or varieties (Olson and Sander, 1992). Generally, Tisdale et al. (1993) quantified the concentration of $P$ in most plants to be between 0.1 and $0.4 \%$, the large amounts being found in seed and fruits. However, they recommend analysis of all plant parts to measure the total $\mathrm{P}$ quantity. Realizing the importance of generating research results under Ethiopian condition, a field experiment was conducted in the 2000 main rainy season on an agriculturally dominant soil (Andosol) in Arsi Neggele, Ethiopia. The main objective of the study was to determine the relative efficiency of different phosphorous fertilizer placement methods and maize genotypes as expressed in the available soil $P$, uptake and apparent recovery of $P$ in maize varieties. The need of investigating the interaction effect among the various $P$ nutrient parameters in relation to placement also encouraged the undertaking of such experiment.

\section{MATERIALS AND METHODS}

The experiment was conducted in Arsi Neggele Agricultural SubResearch Center (Ethiopia) at an altitude of 1960 meters above sea level (masl), latitude $7^{\circ} 20^{\prime}$ North and longitude of $38^{\circ} 9^{\prime}$ East. The soils of the area are classified as Andosol (Ho, 1992), and the average annual precipitation of the last ten years is $990 \mathrm{~mm}$.

The treatments considered in this experiment were five methods of $\mathrm{P}$ fertilizer placement and four maize varieties. The $\mathrm{P}$ placement treatments used were broadcasting $(\mathrm{BC})$ or the control of the $\mathrm{P}$ placement, row drilling (RD), point placement at a side for a single seed (PPS), point placement between two seeds (PPD) and no $P$ placement of the absolute check (NPP). Likewise, the four maize crop varieties used in this experiment were local variety (Shaye), locally synthesized Bako hybrid (BH-540), pioneer hybrid (PHB$3253)$, and open pollinated improved variety (A-511). The sub plot and main plot treatments consisting of 20 treatment combinations were laid out in a split plot design with varieties as main plots and methods of fertilizer placements as sub plot treatments with three replications. Individual plot size of $12 \mathrm{~m}^{2}(2.5 \mathrm{~m} \times 4.8 \mathrm{~m})$ was planted at population rate of 50,000 plants/ha through considering each plot as an experimental unit. Rate of fertilizer (DAP and urea) application and farm management practices are used as per the recommendations released for the area. Consequently, the rate of applied net $P$ for all $P$ placed treatments was $20 \mathrm{~kg} \mathrm{P} / \mathrm{ha}$.

Twenty-one composite surface soil (0 to $25 \mathrm{~cm}$ depth) samples (one of them before planting) and 20 composite plant tissue samples of grains and stovers were collected and analyzed in the laboratory. The analyses were carried out following the procedures in the Analytical Service Laboratory of the International Livestock and Research Institute (ILRI), Addis Ababa. The over all $P$ nutrient and other relevant parameters considered and recorded under the study include soil color, texture, and $\mathrm{pH}$ (before planting); total $\mathrm{N}$, available and total $\mathrm{P}$ (both before planting and after harvest); tissue $\mathrm{P}$ and $\mathrm{N}$ concentration of the grains and stover; $\mathrm{P}$ uptakes in grains, stovers and whole above ground plant parts; and apparent $\mathrm{P}$ recovery.

To compute the total plant $\mathrm{P}$ uptake, the $\mathrm{P}$ uptake by grains and stover were first determined by multiplying the dry weight of these parts by their respective $P$ concentration. Total $P$ uptake was then calculated as the sum of the grain $P$ uptake and the stover $P$ uptake $(\mathrm{kg} / \mathrm{ha})$. Finally, percent $\mathrm{P}$ nutrient recovery was computed as: $100\left(U_{P}-U_{0}\right) / P$, where $U$ stands for total plant $P$ uptake of each treatment at $\mathrm{p}$, the applied $\mathrm{P}$ and $\mathrm{o}$, zero or no $\mathrm{P}$ applied plots. Nutrient uptakes were subjected to analysis of variance considering plant $\mathrm{N}$ concentration as covariant using MSTAT computer software. Simple linear correlation coefficients were also computed using the same software. The mathematical model of the correlation function is: $Y=\alpha+\beta X$, where $\alpha$ is the intercept of the line on the $Y$ axis and $\beta$, is the amount of change in $Y$ for each unit change in $X$ (Gomez and Gomez, 1984). Heterogeneity was detected statistically by using Hartley's test (F-max statistic). Adjusted crude means were separated using the LSD test.

\section{Some soil properties of the study area}

The surface soil (25 $\mathrm{cm}$ depth) of the experimental site was dark brown (7.5YR3/2) when moist and very dark grayish brown (10YR3/2) when dry in color, and clay loam in texture. It has almost a neutral soil reaction with a $\mathrm{pH}$ value of 6.9 as measured in a 1:1 soil water suspension (Table 1). Fisseha (1982) reported a pH value of 6.3 for the surface 0 to $20 \mathrm{~cm}$ depth of the adjacent soil under similar measurement conditions. This indicates that the $\mathrm{pH}$ level of the soil has been increasing gradually over the last two decades. The total nitrogen, available phosphorous and total phosphorous of the experimental site before planting was $0.14 \%$, $13.1 \mathrm{ppm}$, and $236.6 \mathrm{ppm}$, respectively (Table 1 ). These analytical values indicated that the soil is medium both in hoard nitrogen and phosphorus status.

\section{RESULTS AND DISCUSSION}

\section{Available soil $\mathbf{P}$}

The Bray-II extractant available soil P showed an increase with the application of $P$ in the form of di-ammonium phosphate with considerable differences across placement methods, genotypes and their combined effect (Table 2 and Figure 1). When averaged over all maize varieties, the initial level of available soil $P$ that was 13.1 ppm before sowing increased to 14.0, 21.7 and $47.4 \mathrm{ppm}$ when row drilling (RD), point placement at a side (PPS) and point placement between two adjacent seeds (PPD) of $P$ fertilizer placements were used, respectively. Among the above three methods of $P$ placements, the highest soil available $\mathrm{P}$ level of increment was obtained by the 
Table 1. Some soil properties of the study site before planting

\begin{tabular}{|c|c|c|c|c|c|c|c|c|c|}
\hline \multicolumn{2}{|l|}{ Color } & \multirow{3}{*}{$\mathrm{pH}$} & \multicolumn{4}{|c|}{ Particle size distribution (\%) } & \multicolumn{3}{|c|}{ Nutrient concentration } \\
\hline \multirow{2}{*}{ Dry } & \multirow{2}{*}{ Moist } & & \multirow{2}{*}{ Clay } & \multirow{2}{*}{ Silt } & \multirow{2}{*}{ Sand } & \multirow{2}{*}{ Textural class } & \multicolumn{2}{|c|}{$P(p p m)$} & \multirow{2}{*}{ Total N (\%) } \\
\hline & & & & & & & Total & Avail. & \\
\hline $\begin{array}{l}\text { Very dark grayish } \\
\text { brown (10YR3/2) }\end{array}$ & $\begin{array}{l}\text { Dark brown } \\
\text { (7.5 YR 3/2) }\end{array}$ & 6.9 & 36 & 30 & 34 & Clay loam & 236.60 & 13.10 & 0.14 \\
\hline
\end{tabular}

Table 2. Concentration of available $P(\mathrm{ppm})$ in the soil after harvest.

\begin{tabular}{lcccccc}
\hline \multirow{2}{*}{ Maize varieties } & \multicolumn{6}{c}{ Phosphorus placement methods } \\
\cline { 2 - 7 } & BC & RD & PPS & PPD & NPP & Mean \\
\hline Local & 7.33 & 12.06 & 13.35 & 74.21 & 3.91 & 22.18 \\
BH-540 & 4.97 & 8.92 & 24.57 & 52.3 & 3.54 & 18.86 \\
PHB-3253 & 13.35 & 21.84 & 24.93 & 44.83 & 4.35 & 21.86 \\
A-511 & 11.56 & 13.09 & 23.86 & 18.38 & 4.55 & 14.29 \\
Means & 9.3 & 13.98 & 21.68 & 47.43 & 4.1 & \\
\hline
\end{tabular}

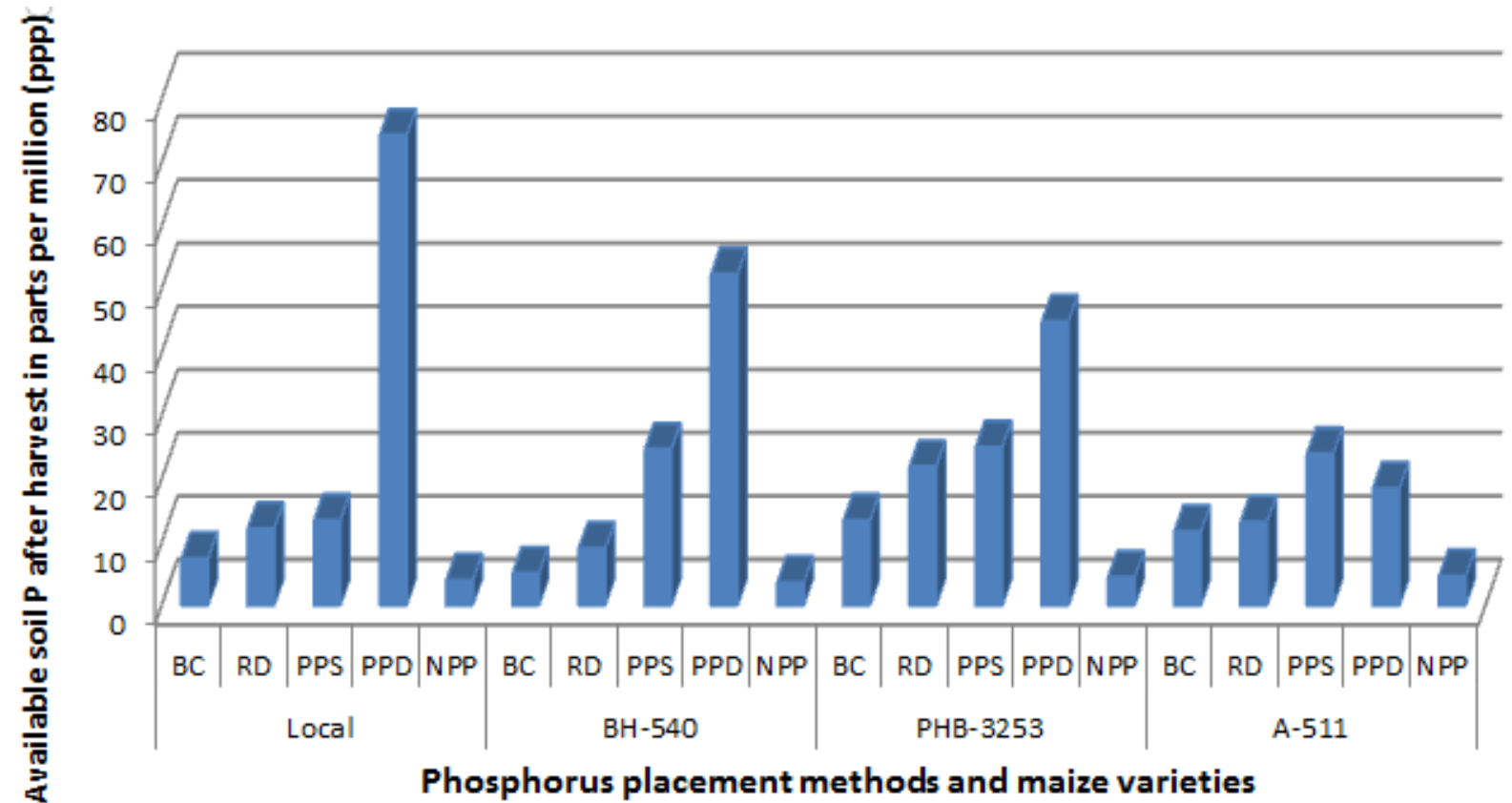

Figure 1. Variations in available soil $P$ after harvest as affected by the five $P$ placement methods under each maize variety. BC - broadcasting, RD - row drilling, PPS - point placement at a side for single seed, PPD - point placement between two seeds, and NPP - no P placement.

use of PPD (34.7 ppm) and the lowest by using RD (0.9 $\mathrm{ppm}$ ) methods of $\mathrm{P}$ application. This highest level of BrayII soil resulted due to PPD method of fertilizer application coincides with the superior result of grain, stover and plant $\mathrm{P}$ uptake obtained due to the same placement method, PPD.

From such result, it can be learnt that the variation of
Bray-II $P$ as affected by $P$ placement methods has less to do with the subsequent $P$ uptake pattern of the maize plant. This might be because of the presence of enough reserve $\mathrm{P}$ in the soil solution before fresh $\mathrm{P}$ application, which was accounted to be $13.1 \mathrm{ppm}$ (Table 1). In line with this study, Olsen and Sander (1992) also reported that maize response was quite unlikely when the soil test 
value is greater than $15 \mathrm{mg} / \mathrm{kg}$ (Bray and Kurtz-l). The present finding also agrees with the concept of critical concentration (CC) that stated no crop response was expected at and above CC values (Olsen and Sander, 1992). Mallarino and Blackmer (1992) determined the CC value of maize crop to be $13 \mathrm{mg} / \mathrm{kg}$ for Bray-l and 5 $\mathrm{mg} / \mathrm{kg}$ for Olsen extractant, which could be in equivalent range to the pre planting available soil $P$ test Bray-II value (13.1 ppm) of this experiment (Table 1). Without $P$ application treatment, the available soil $\mathrm{P}$ decreased from 13.1 to $4.10 \mathrm{ppm}$ implying that about $9 \mathrm{ppm}$ of available soil $\mathrm{P}$ was lost through either absorption by the maize crop, or fixation, or both. Relative to the non $P$ treated plots, the available soil P test for BC, RD, PPS and PPD placement methods increased by 5.20, 9.88, 17.58 and $43.33 \mathrm{ppm}$, respectively. Thus, apart from plant $\mathrm{P}$ uptake, loss of available $P$ in the applied phosphate with $B C$ method was higher than that of PPD and RD methods. This could be attributed to the possibility of high $P$ fixation in the soil due to increased $P$ adsorption surfaces with the BC method. The results reported by Tisdale et al. (1993); Miller and Donahaue (1995) and Ouyang et al. (1999) also disclosed similar phenomenon.

Similarly, when averaged over all sub plot treatments, the level of available soil P (after harvest) also varied with the different maize varieties planted as test genotypes (Table 2 and Figure 1). Unlike with the effect of $P$ placement methods, all genotypes increased the initial level of available $P$ test value to varying levels. Here, the highest amount of Bray-II extractable soil $\mathrm{P}$ (22.2 ppm) was obtained from the plots where local cultivar was grown, while the least value (14.3 ppm) was recorded from the plots where A-511 was grown (Table 2 and Figure 2). Generally, the range of variation of available soil $\mathrm{P}$ after harvest was relatively wider for comparisons among the four $P$ placement methods than for comparisons among the four maize genotypes (Figure 1). The extreme differences within each other, for instance, were $38.13 \mathrm{ppm}$ for $\mathrm{P}$ placement methods and $7.89 \mathrm{ppm}$ due to the effect of the maize genotypes. Based on the laboratory test of the initial soil and the amount applied in the form of fertilizer, the available $P$ reserve of the soil following volume to mass conversion concept is computed to be 32.8 and $52.8 \mathrm{~kg} \mathrm{P} / \mathrm{ha}$ before and after fertilizer application, respectively. The total $\mathrm{P}$ reserve both after fresh $P$ fertilizer application ( $52.8 \mathrm{~kg} \mathrm{P} / \mathrm{ha})$ and even before $(32.8 \mathrm{~kg} \mathrm{P} / \mathrm{ha})$ was much higher than the highest value $(29.5 \mathrm{~kg} \mathrm{P} / \mathrm{ha})$ of $\mathrm{P}$ absorption by the maize plant (Table 2).

\section{Total soil $\mathbf{P}$}

In accordance with available soil P, PPD followed by PPS resulted in the highest total $P$ values among the $P$ placement methods and local cultivar followed by PHB-
3253 among the maize genotypes (Table 3). Similarly, NPP followed by BC among the $\mathrm{P}$ placement methods and $\mathrm{A}-511$ followed by $\mathrm{BH}-540$ among the maize genotypes resulted the lowest total soil $P$ test value. Figures 3 and 4 depict such similar trend as affected by the three factors under investigation. Generally, the over all concentration of total soil $P$ test level of the experimental site which accounted in a range of about 46 to $98 \mathrm{~kg} \mathrm{P} / \mathrm{ha}$ could be regarded as high. The volcanic origin of the experimental site combined with the consecutive application of artificial phosphate fertilizer from year to year might contribute to generally high level of total soil phosphorus.

\section{Concentration of $\mathbf{P}$ in plant tissues}

As illustrated in Figures 2 and 3 , the levels of the variation of the values of $P$ concentration of the three maize plant parts (grain, stover and total above ground parts) are apparently varied to one another. On the other hand, the level of distribution of $P$ concentration in each of the maize plant tissues (grain, stover and total above ground parts) as shown in Figures 2 and 3 is less or modestly scattered in response to both $\mathrm{P}$ placement methods and genotype. Thus, the variation of $P$ concentration in the different parts of the maize plant to the two factors under the study as represented by the line graphs is almost liner to moderately skew within each other. Though these values looks less variable and inconsistent (Figures 2 and 3 ), the subsequent values of the uptakes analyzed with the help of statistical tools confirm that uptake responses were in most cases statistically significant as affected by the main plot and sub plot treatments as well as by their interaction. Detailed analysis and discussions of $P$ uptakes are thus presented in the sections below. The results of the laboratory determination on the concentrations (\%) of $\mathrm{P}$ in maize grains $(0.212$ to $0.310 \%)$ and stover $(0.025$ to $0.064 \%)$ showed that $P$ concentration was greater in the grains than in the stover. In line with this finding, Tisdale et al. (1993) reports that the large quantities of $P$ storage are the grains and fruits of plants. The result of this experiment on total plant tissue content $(0.237$ to $0.374 \%)$ was also within the range $(0.1$ to $0.4 \%)$ given by the same authors.

\section{Phosphorus uptake responses}

Phosphorus placement methods highly significantly affected $P$ uptake in both plant parts (grain and stover) and consequently total plant $P$ uptake (Table 4). It also revealed that maize varieties (main plot) also affected highly significantly the stover and total plant $P$ uptake while its effect on grain $\mathrm{P}$ uptake was non-significant. Such responsive nature of some varieties is in agreement 


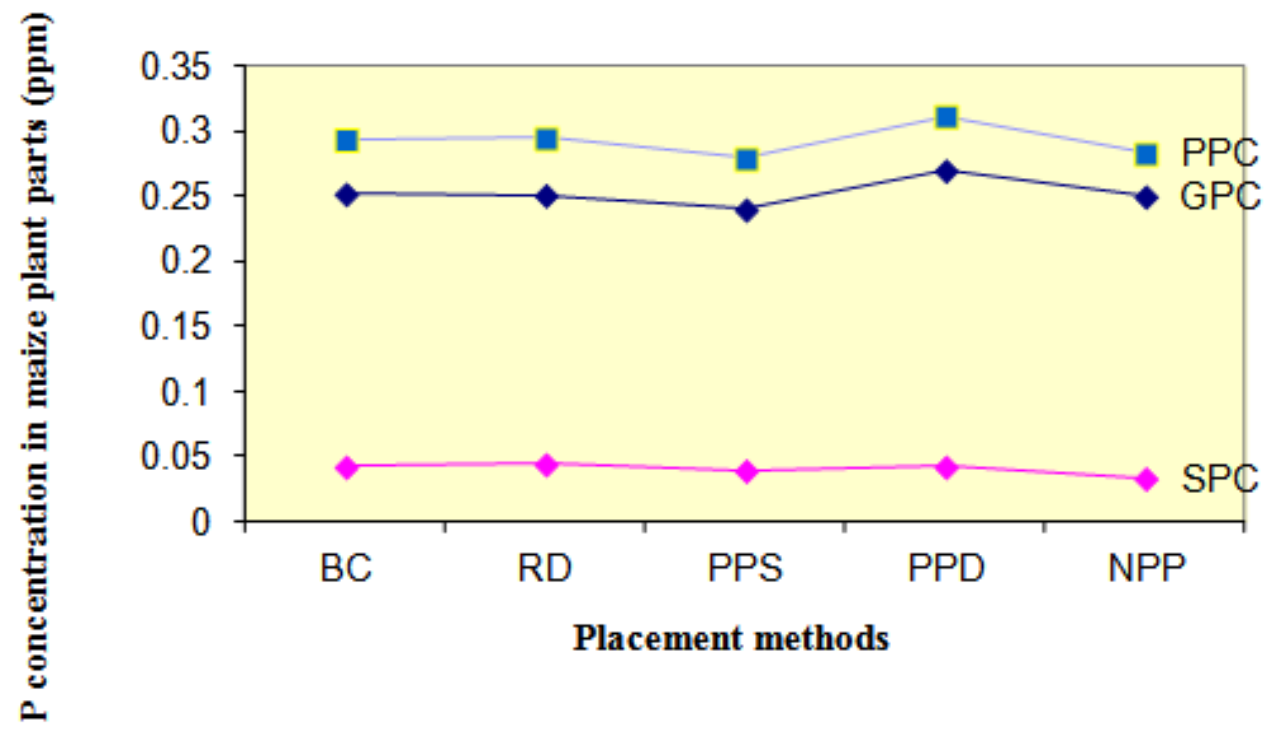

Figure 2. Scattered and line trend distribution of maize $P$ concentration in maize plant parts (grain, stover and whole above ground) as affected by $\mathrm{P}$ placement methods. PPC - plant $\mathrm{P}$ concentration, GPC - grain P concentration, SPC - stover P concentration, BC - broadcasting, RD - row drilling, PPS - point placement at one side of a single seed, PPD - placement between two seeds, and NPP - no P applied treatment/plots.

Table 3. Concentration of total $\mathrm{P}(\mathrm{ppm})$ in the soil after harvest.

\begin{tabular}{lcccccc}
\hline \multirow{2}{*}{ Maize varieties } & \multicolumn{7}{c}{ Phosphorus placement methods } \\
\cline { 2 - 7 } & BC & RD & PPS & PPD & NPP & Mean \\
\hline Local & 227.93 & 295.94 & 343.04 & 390.69 & 205.43 & 292.61 \\
BH-540 & 216.62 & 216.62 & 307.51 & 319.49 & 183.42 & 248.73 \\
PHB-3253 & 261.49 & 261.49 & 319.22 & 250.43 & 205.43 & 259.61 \\
A-511 & 183.42 & 238.87 & 216.50 & 227.93 & 216.62 & 216.67 \\
Means & 222.37 & 253.23 & 296.57 & 297.14 & 202.73 & \\
\hline
\end{tabular}

with the study of Jensen and Hauggaard (2003) who reported that deep rooting system of some species and varieties contributes to efficient nutrient utilization. The interaction between the maize varieties and $P$ placement methods also revealed a highly significant effect on stover and plant $P$ uptake and a significant $(p \leq 0.05)$ effect on grain $P$ uptake (Table 4). The presence of interaction effect on $P$ uptake implied that varietal effect varied with varied effect of $\mathrm{P}$ placement methods and vice versa. Hence, no consistent uptake response is expected under all maize varieties due to $P$ placement treatments or under all $\mathrm{P}$ placement methods due to maize genotypes.

\section{Grain P uptake}

Methods of $P$ placement imposed a significant variation in grain $\mathrm{P}$ uptake of all maize varieties except on Bako hybrid (BH-540), which showed no significant difference over all placement treatments. Under all varieties, except $\mathrm{BH}-540$ that appeared insignificant, the highest significant $(p \leq 0.05)$ grain $P$ uptake means were obtained under PPD (15.8 to $16.2 \mathrm{~kg} / \mathrm{ha}$ ) followed by RD (13.8 to 15 $\mathrm{kg} / \mathrm{ha}$ ). In the case of local cultivar, BC, PPS and NPP produced non-significantly different mean values with each other. Among the treatment combination, the highest mean grain $\mathrm{P}$ uptake $(16.2 \mathrm{~kg} / \mathrm{ha})$ was recorded from the interaction between PPD and the pioneer hybrid (PHB-3253) followed by the interaction of PPD and A-511. On the contrary, the least $(9.1 \mathrm{~kg} \mathrm{P} / \mathrm{ha})$ mean of grain $P$ uptake belongs for the combination between NPP and the local maize cultivar.

\section{Stover $\mathbf{P}$ uptake}

Phosphorus placement methods highly significantly affected stover $P$ uptake and significantly $(p \leq 0.05)$ 

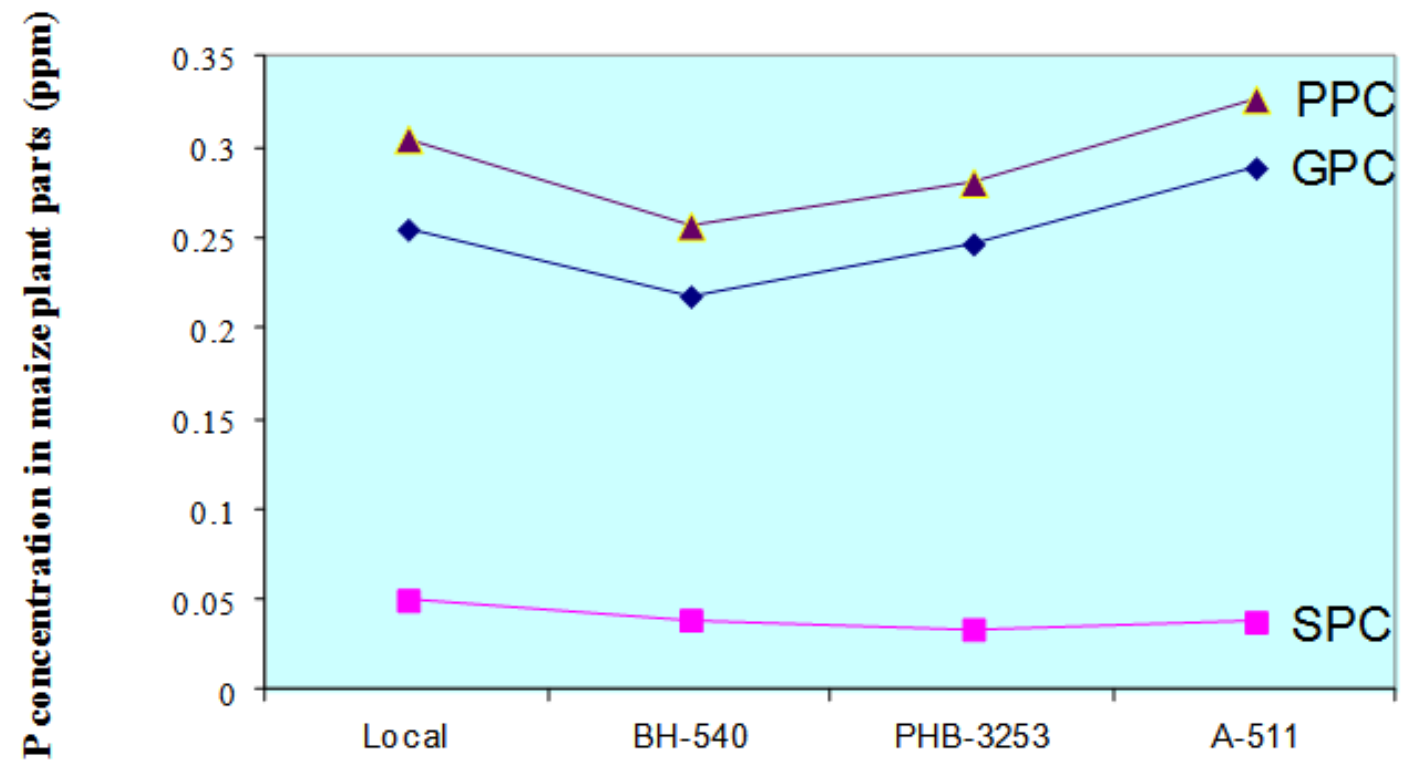

Maize varieties (genotype)

Figure 3. Scattered and line trend distribution of $P$ concentration in maize plant parts (grain, stover and whole above ground) as affected by maize genotype. PPC - plant P concentration, GPC - grain P concentration, and SPC - stover P concentration.

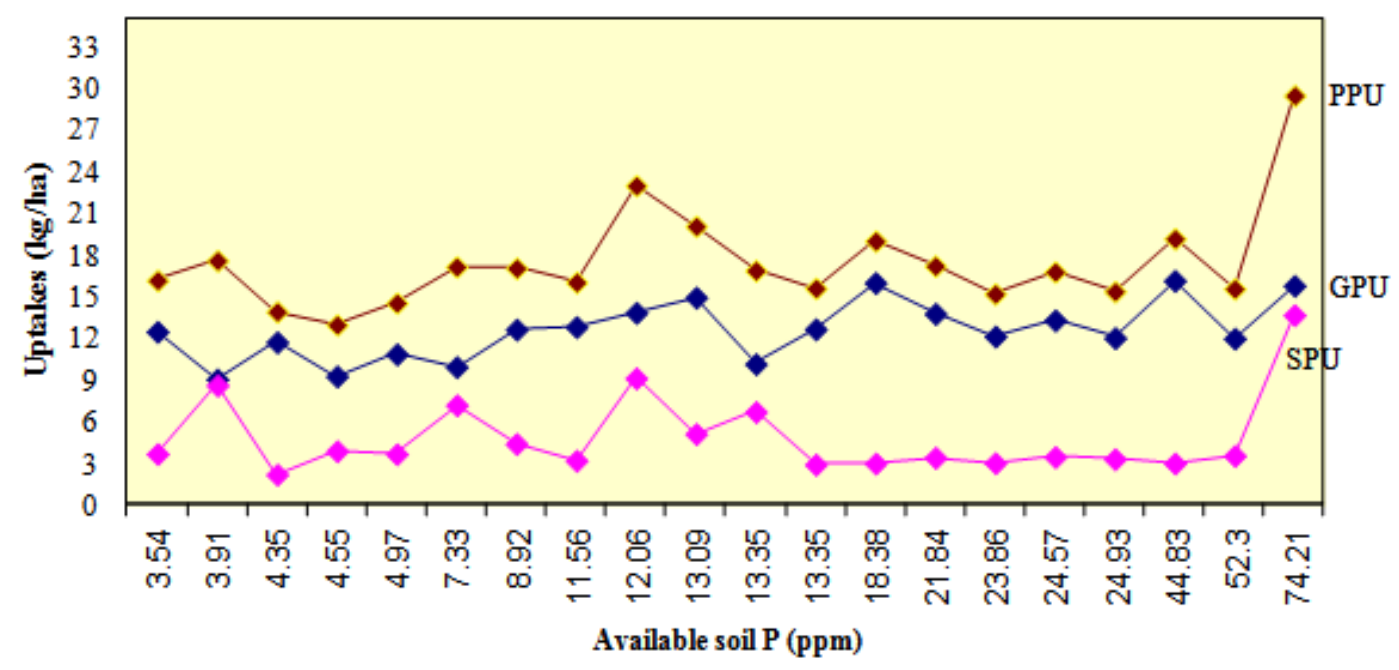

Figure 4. Functional relationship between available soil $P$ and $P$ uptakes in plant parts (grain, stover and whole maize plant). PPU - plant P uptake, GPU - grain P uptake, SPU - stover P uptake, and kg/hakilograms per hectare.

affected all maize varieties except $\mathrm{BH}-540$. For instance, under the local cultivar, a significant different $(p \leq 0.05)$ in stover $\mathrm{P}$ uptake means was observed between that of PPD and RD or NPP, and between BC or PPS and the former three placement methods. With the local maize variety, the highest and significant mean stover $\mathrm{P}$ uptake of $13.7 \mathrm{~kg}$ P/ha was produced by PPD method (followed by RD method), which is more than double of the least mean value (6.7) of the same local cultivar. Among genotypes, means of $\mathrm{P}$ uptake by stover were the highest $(13.7 \mathrm{~kg} / \mathrm{ha})$ for the local cultivar among the rest of the varieties under all placement methods. On the other 
Table 4. Mean square values for $P$ nutrient uptake by maize varieties as analysed for split plot design.

\begin{tabular}{|c|c|c|c|c|c|}
\hline \multirow[t]{2}{*}{ Nutrient uptake parameters } & \multicolumn{5}{|c|}{ Mean squares } \\
\hline & $V(3)$ & Error-a (6) & M (4) & $V \times M(12)$ & Error-b (31) \\
\hline Grain P uptake (kg/ha) & $7.35 n s$ & 2.90 & $30.40^{\star *}$ & $6.84^{*}$ & 3.14 \\
\hline Stover $\mathrm{P}$ uptake $(\mathrm{kg} / \mathrm{ha})$ & $99.53^{\star *}$ & 0.39 & $3.09^{* *}$ & $3.81^{* *}$ & 0.47 \\
\hline Plant $P$ uptake $(\mathrm{kg} / \mathrm{ha})$ & $58.99^{* *}$ & 4.11 & $51.27^{\star \star}$ & $14.57^{\star \star}$ & 4.78 \\
\hline
\end{tabular}

${ }^{*} \&{ }^{* *}$-Significant at $5 \%$ \& $1 \%$ probability levels, respectively, ns-Non-significant. The figures in parenthesis are the degrees of freedom (df) for the receptive sources of variation. V - Maize varieties, $M$ - P placement methods, $V \times M$ - Interaction between variety and $P$ placement method.

hand, the lowest mean stover $\mathrm{P}$ uptake of $2.2 \mathrm{~kg} \mathrm{P} / \mathrm{ha}$ was recorded for the pioneer hybrid (PHB-3253) grown without $\mathrm{P}$ application (NPP). This apparently agrees with the most frequently observed very low yielding characteristics of improved varieties and/or hybrids in the absence of all the necessary inputs including fertilizer. Moreover such result was in agreement with the concurrent 'an add-on effect' principle of Tisdale et al. (1993). As far as treatment interaction is concerned, the highest stover $\mathrm{P}$ uptake (13.7 $\mathrm{kg} \mathrm{P} / \mathrm{ha}$ ) was produced by the combined effect of PPD and the local maize cultivar, whereas the least $(2.2 \mathrm{~kg} / \mathrm{ha})$ performing combination was when pioneer hybrid was planted without $P$ fertilizer. The reason for the highest response of stover $\mathrm{P}$ uptake to the combination of PPD with local cultivar might be attributed to the genetic trait of the local cultivar combined with the proper $\mathrm{P}$ placement method. The vigor vegetative growth of the local maize observed in the field must be root from its genetic make up and might probably be associated with efficient activity of its root system. This enabled the plant to effectively trap the $P$ nutrient from the soil to accumulate it, probably, in the vacuoles of the stover plant part (Bieleski and Ferguson, 1983).

\section{Total maize plant $\mathbf{P}$ uptake}

Phosphors placement is significantly $(p \leq 0.05)$ affected plant $\mathrm{P}$ uptake on all maize varieties except for the locally synthesized hybrid, $\mathrm{BH}-540$. Under local cultivar, PPD revealed the highest $(29.5 \mathrm{~kg} \mathrm{P} / \mathrm{ha})$ total plant $\mathrm{P}$ uptake followed by row drilling method (Table 5). Likewise, the mean result of plant $P$ uptake observed under $A-511$ also favored the PPD and RD methods than BC method of $P$ application, which was in agreement with the result obtained by Lu et al. (1987) and Mallarino et al. (1999). Pablo et al. (2014) also reported that broadcasted P resulted in lower $P$ accumulation than deep-banded $P$ at tillering stage. Similarly, maize varieties caused significant $(p \leq 0.05)$ variation on mean total plant $P$ uptake under three (RD, PPD and NPP) among the five placement methods and non-significant variation under the remaining two (BC and PPS) $P$ placement treatments (Table 6).
Under the four P placement methods, the uptake means of the local cultivar exceeded that of all improved varieties (Table 6). Without fertilizer (NPP), the local cultivar produced the highest plant $\mathrm{P}$ uptake value, although it remained statistically at par with the means produced by the two maize hybrids (BH-540 and PHB-3253) (Table 6). Relative to the others treatment combinations, the highest and significant $(p \leq 0.05)$ mean plant $P$ uptake $(29.5 \mathrm{~kg}$ $\mathrm{P} / \mathrm{ha}$ ) was observed from the interaction of the local cultivar with PPD method of P placement followed in this order by the combinations between RD and the same local maize genotype, and RD and A-511 (Table 7). The highest plant $\mathrm{P}$ uptake of $29.54 \mathrm{~kg} \mathrm{P} / \mathrm{ha}$ of the local cultivar grown under PPD (Table 7) is greater than the freshly applied $P(20 \mathrm{~kg} P / \mathrm{ha})$ from artificial phosphate source. This indicated that the local variety planted by PPD method of $P$ application efficiently absorbed $P$ nutrient from both originally available and freshly applied $P$ compared to all of the remaining 19 treatment combinations. Its efficiency in nutrient absorption could also be reflected to highest yield effect.

\section{Recovery of $\mathbf{P}$ nutrient}

The apparent recovery of $\mathrm{P}$ nutrient varied both among the $P$ placement methods and maize varieties as well as for the interaction effect (Table 8). Similarly, when averaged over all $\mathrm{P}$ placement methods, the four maize varieties revealed differences in $\mathrm{P}$ nutrient recovery within each other (Table 8). The highest percentage was computed for the variety A-511 $(22.7 \%)$ followed by the Arsi Neggele local cultivar (20.2\%) and the pioneer hybrid $(14.6 \%)$ while the least was recorded for Bako hybrid (BH-540) (Table 8). As far as all of the treatment combinations are concerned, the highest percentage of $P$ recovery was registered for the combined effect of the local cultivar and PPD method of $P$ application (59.6\%) followed by the combination between A-511 and row drilling method of $P$ fertilizer application. On the other hand, the least $P$ recovery percentage was recorded when Bako hybrid (BH-540) were planted in the plots where $\mathrm{P}$ fertilizer was broadcasted over the entire surface $(-8.2 \%)$. This indicate that the response obtained by the 
Table 5. Mean estimate of plant $P$ uptake $(\mathrm{kg} \mathrm{P} / \mathrm{ha})$ and comparisons of response to $\mathrm{P}$ placement methods within main plot treatment.

\begin{tabular}{|c|c|c|c|c|c|c|}
\hline \multirow{2}{*}{ Maize varieties } & \multicolumn{6}{|c|}{ Phosphorus placement methods* } \\
\hline & BC & RD & PPS & PPD & NPP & Mean \\
\hline Local & $17.19^{c}$ & $23.04^{\mathrm{b}}$ & $16.92^{\mathrm{c}}$ & $29.54^{\mathrm{a}}$ & $17.63 \mathrm{c}$ & 20.86 \\
\hline $\mathrm{BH}-540$ & $14.58^{\mathrm{a}}$ & $17.09^{\mathrm{a}}$ & $16.82^{\mathrm{a}}$ & $15.60^{\mathrm{a}}$ & $16.21^{a}$ & 16.06 \\
\hline PHB-3253 & $15.64^{\mathrm{ab}}$ & $17.25^{\mathrm{ab}}$ & $15.40^{b}$ & $19.21^{\mathrm{a}}$ & $13.96^{b}$ & 16.29 \\
\hline$A-511$ & $16.07^{\mathrm{bc}}$ & $20.11^{a}$ & $15.23^{\mathrm{C}}$ & $19.05^{\mathrm{ab}}$ & $13.08^{\mathrm{C}}$ & 16.71 \\
\hline Mean & 15.87 & 19.37 & 16.09 & 20.85 & 15.22 & \\
\hline
\end{tabular}

$\operatorname{LSD}(0.05)=3.639 ; \mathrm{CV}(\%)=12$. 50: For placement means within a main plot. *Means within a row followed by the same letter(s) are not significantly different at 0.05 level of probability. BC-broadcasting, RD-row drilling, PPS - point placement at a side for single seed, PPD-point placement between two seeds, and NPP - no P placement.

Table 6. Mean estimate of plant $\mathrm{P}$ uptake ( $\mathrm{kg} \mathrm{P} / \mathrm{ha}$ ) and comparisons of response to maize variety within sub plot treatment.

\begin{tabular}{lcccccc}
\hline \multirow{2}{*}{ Maize varieties* $^{*}$} & BC & RD & PPS & PPD & NPP & Mean \\
\cline { 2 - 7 } & $17.19^{\mathrm{a}}$ & $23.04^{\mathrm{a}}$ & $16.92^{\mathrm{a}}$ & $29.54^{\mathrm{a}}$ & $17.63^{\mathrm{a}}$ & 20.86 \\
Local & $14.58^{\mathrm{a}}$ & $17.09^{\mathrm{b}}$ & $16.82^{\mathrm{a}}$ & $15.60^{\mathrm{b}}$ & $16.21^{\mathrm{ab}}$ & 16.06 \\
BH-540 & $15.64^{\mathrm{a}}$ & $17.25^{\mathrm{b}}$ & $15.40^{\mathrm{a}}$ & $19.21^{\mathrm{b}}$ & $13.96^{\mathrm{ab}}$ & 16.29 \\
PHB-3253 & $16.07^{\mathrm{a}}$ & $20.11^{\mathrm{ab}}$ & $15.23^{\mathrm{a}}$ & $19.05^{\mathrm{b}}$ & $13.08^{\mathrm{b}}$ & 16.71 \\
A-511 & 15.87 & 19.37 & 16.09 & 20.85 & 15.22 & \\
Mean & &
\end{tabular}

$\operatorname{LSD}(0.05)=3.6727 ; \mathrm{CV}(\%): 11.60$ : For genotype means within a sub plot. *Means within a column followed by the same letter(s) are not significantly different at 0.05 level of probability. BC - broadcasting, RD - row drilling, PPS - point placement at a side for single seed, PPD - point placement between two seeds, and NPP - no P placement.

Table 7. Mean estimate on plant $P$ uptake $(\mathrm{kg} \mathrm{P} / \mathrm{ha})$ and comparisons of response to interaction between $\mathrm{P}$ placement methods and maize genotype

\begin{tabular}{lcccccc}
\hline \multirow{2}{*}{ Maize varieties } & \multicolumn{5}{c}{ Phosphorus placements methods } \\
\cline { 2 - 7 } & BC & RD & PPS & PPD & NPP & Mean \\
\hline Local & $17.19^{\text {cdef }}$ & $23.04^{\text {b }}$ & $16.92^{\text {cdef }}$ & $29.54^{\text {a }}$ & $17.63^{\text {cde }}$ & 20.86 \\
BH-540 & $14.58^{\text {efg }}$ & $17.09^{\text {cdef }}$ & $16.82^{\text {cdef }}$ & $15.60^{\text {defg }}$ & $16.21^{\text {defg }}$ & 16.06 \\
PHB-3253 & $15.64^{\text {defg }}$ & $17.25^{\text {cdef }}$ & $15.40^{\text {efg }}$ & $19.21^{\text {cd }}$ & $13.96^{\text {fg }}$ & 16.29 \\
A-511 & $16.07^{\text {defg }}$ & $20.11^{\text {bc }}$ & $15.23^{\text {efg }}$ & $19.05^{\text {cd }}$ & $13.08^{\text {g }}$ & 16.71 \\
Mean & 15.87 & $19.37^{2}$ & 16.09 & 20.85 & 15.22 & \\
\hline
\end{tabular}

$\operatorname{LSD}(0.05)=3.6727 ; \mathrm{CV}(\%)=12.50$ : For means across all rows and columns. *Means across all rows and columns followed by the same letter(s) are not significantly different at 0.05 level of probability. BC-broadcasting, RD-row drilling, PPS-point placement at a side for single seed, PPD-point placement between two seeds, and NPP-no P placement.

combination of $\mathrm{BH}-540$ planted using the broadcasted $\mathrm{P}$ fertilizer was less by $8.2 \%$ than that of the response of the same maize hybrid (BH-540) planted with out $\mathrm{P}$ fertilizer. Based on the result of $\mathrm{BH}-540$, it seems that the plants have absorbed more of the residual $\mathrm{P}$ while much of the broadcasted $P$ was remained in the soil without being absorbed by the plant. This may be attributed to the inefficiency of the broadcasting method combined with the probably low root interception capacity of the hybrid $(\mathrm{BH}-$ 540) variety. This is inline with the reasoning described by
Mallarino et al. (1999). It is also obvious that increased availability is not always reflected in increased uptake of the specific nutrient by crop plants.

\section{Linear and functional interrelationship of $P$ nutrient parameters}

Available soil $\mathrm{P}$ after harvest was correlated positively and highly significantly with total soil $\mathrm{P}$, grain $\mathrm{P}$ uptake, stover 
Table 8. Computed percentage of apparent $\mathrm{P}$ nutrient recovery

\begin{tabular}{lccccc}
\hline \multirow{2}{*}{ Maize varieties } & \multicolumn{5}{c}{ Phosphorus placement methods } \\
\cline { 2 - 6 } & BC & RD & PPS & PPD & Mean \\
\hline Local & -2.22 & 27.05 & -3.58 & 59.55 & 20.20 \\
BH-540 & -8.17 & 4.43 & 3.05 & -3.05 & -0.93 \\
PHB-3253 & 8.35 & 16.45 & 7.18 & 26.22 & 14.55 \\
A-511 & 14.92 & 35.12 & 10.72 & 29.85 & 22.65 \\
Mean & 3.22 & 20.76 & 4.34 & 28.14 & \\
\hline
\end{tabular}

$\mathrm{BC}$ - broadcasting, RD - row drilling, PPS - point placement at a side for single seed, PPD - point placement between two seeds, and NPP - no P placement.

Table 9. Association among $P$ nutrient parameters as expressed by correlation coefficients ( $r$ ).

\begin{tabular}{|c|c|c|c|c|c|c|c|c|}
\hline Parameter & ASP & TSP & GPC & SPC & GPU & SPU & PPU & APR \\
\hline ASP & 1.000 & & & & & & & \\
\hline TSP & $0.713^{\star *}$ & 1.000 & & & & & & \\
\hline GPC & 0.108 & -0.205 & 1.000 & & & & & \\
\hline SPC & $0.318^{*}$ & $0.432^{* *}$ & 0.072 & 1.00 & & & & \\
\hline GPU & $0.458^{* *}$ & 0.214 & $0.376^{* *}$ & 0.101 & 1.000 & & & \\
\hline SPU & $0.350^{* *}$ & $0.497^{* *}$ & 0.120 & $0.776^{* *}$ & 0.078 & 1.000 & & \\
\hline PPU & $0.546^{* *}$ & $0.496^{* *}$ & $0.326^{*}$ & $0.624^{* *}$ & $0.694^{* *}$ & $0.771^{* *}$ & 1.000 & \\
\hline APR & $0.386^{* *}$ & 0.019 & $0.495^{\star *}$ & 0.285 & $0.828^{* *}$ & $0.435^{\star *}$ & $0.806^{* *}$ & 1.000 \\
\hline
\end{tabular}

${ }^{*} \&^{* *}$ : - Significant at $5 \%$ and $1 \%$ probability levels whenever the computed $r$-values were greater than the tabulated values at the $5 \%$ and $1 \%$ levels of significance respectively, and at $n-2$ degree of freedom where $n$ stands for the total number of experimental units or plots (Gomez and Gomez, 1984). The decimal numbers without any astrics are non-significant ( $p>0.05)$ values. ASP - Available soil P after harvest, TSP - Total soil P after harvest, GPC - Grain P concentration, SPC-Stover P concentration, GPU - Grain P uptake, SPU Stover $P$ uptake, PPU - Plant P uptake, APR - Apparent P recovery.

$P$ uptake, plant $P$ uptake and apparent $P$ recovery (Table 9). The less usual direct relationship between Bray-II soil $P$ after harvest and each of the soluble $P$ demanding uptake components may be due to the adequate amount of dissolved $P$ in the soil from the initial soil reserve and applied phosphate fertilizer. Moreover, the total amount of soil available $P$ present during the early period of the experimentation does not mean the plant will take it up all, since uptake is entirely dependent not on the total concentration of available $P$ but on the concentration in the rhizosphere or interfacial boundaries where it can be easily intercepted by plant roots (Tisdale et al., 1993). According to same, the morphological structure of the root system and its inherent physiology also matters. Similarly, total soil $\mathrm{P}$ after harvest showed a highly significant positive correlation with stover $\mathrm{P}$ concentration, stover $\mathrm{P}$ uptake and plant $\mathrm{P}$ uptake. The concentration of $P$ in both the grains and stover were also significantly $(p \leq$ 0.01 ) related with the $P$ uptakes of their respective plant parts. Likewise, plant $P$ uptake was highly significantly correlated with stover $P(r=0.624)$ and significantly with grain $P(r=0.326)$ concentrations and highly significantly with grain $(r=0.694)$ and stover $(r=0.771) P$ uptakes (Table 9). All tissue P nutrient parameters, except stover
$\mathrm{P}$ concentration were directly and strongly related with apparent $P$ recovery percentage (Table 7 ), where the highest correlation coefficient $(r=0.828)$ was with grain $P$ uptake followed by plant $P$ uptake $(r=0.806)$, indicating higher association of the $P$ nutrient recovery with maize grain and whole plant $P$ uptake. On the contrary, the concentration of $P$ in maize stover was not significantly correlated with $\mathrm{P}$ nutrient recovery. Such loose association might be due to the minimal $\mathrm{P}$ storage capacity of the maize stover.

The causal relationships between the dependent variables ( $P$ uptakes) and the independent variables (soil and maize plant tissue $P$ concentrations) as expressed with regression analysis are presented in Table 10. The three $\mathrm{P}$ nutrient uptake parameters showed to be functionally dependent on majority of the $P$ concentration parameters under investigation. As depicted in Table 10 and Figure 4, phosphorus uptakes in grain, stover and total above ground tissues were highly significantly ( $p \leq$ $0.01)$ dependent on available soil $P$. The later two uptake parameters were also highly significantly $(p \leq 0.01)$ dependent on total soil $\mathrm{P}$ and stover $\mathrm{P}$ concentration (Table 10 and Figure 5). Plant $P$ uptake $(p \leq 0.05)$ and $P$ uptake in grains $(p \leq 0.01)$ were also determined by $P$ 
Table 10. Regression analysis of $P$ uptakes parameters by using $P$ nutrient concentrations as independent variables .

\begin{tabular}{|c|c|c|c|c|c|c|c|c|}
\hline \multirow{3}{*}{ Uptakes (DV) } & \multicolumn{8}{|c|}{ Phosphorous nutrient parameters (independent variables) } \\
\hline & \multicolumn{2}{|c|}{ ASPAH } & \multicolumn{2}{|c|}{ TSPAH } & \multicolumn{2}{|c|}{ GPC } & \multicolumn{2}{|c|}{ SPC } \\
\hline & RMS & $r^{2}$ & RMS & $r^{2}$ & RMS & $\mathbf{r}^{2}$ & RMS & $\mathbf{r}^{2}$ \\
\hline GPU & $78.6^{\star *}$ & 0.210 & $17.1 \mathrm{~ns}$ & 0.046 & $53^{\star \star}$ & 0.142 & $3.8 \mathrm{~ns}$ & 0.010 \\
\hline SPU & $59.4^{\star \star}$ & 0.123 & $119.5^{\star *}$ & 0.247 & $6.9 \mathrm{~ns}$ & 0.014 & $291.2^{* *}$ & 0.601 \\
\hline PPU & $275.6^{* *}$ & 0.298 & $228 . .2^{* \star}$ & 0.246 & $98.6^{*}$ & 0.107 & $360.7^{\star \star}$ & 0.390 \\
\hline
\end{tabular}

${ }^{*} \&^{* *}$-Significant at 0.05 and 0.01 probabilities level, respectively, ns-Non-significant, RMS-Regression mean squares, $r^{2}$-Ccoefficient of determination ( $r$-square). DV-Dependent variables, ASPAH-Available soil P after harvest, TSPAH - Total soil P after harvest, GPC - grain P concentration, SPC - Stover P concentration, GPU - Grain P uptake, SPU - Stover P uptake, PPU - Plant P Uptake.

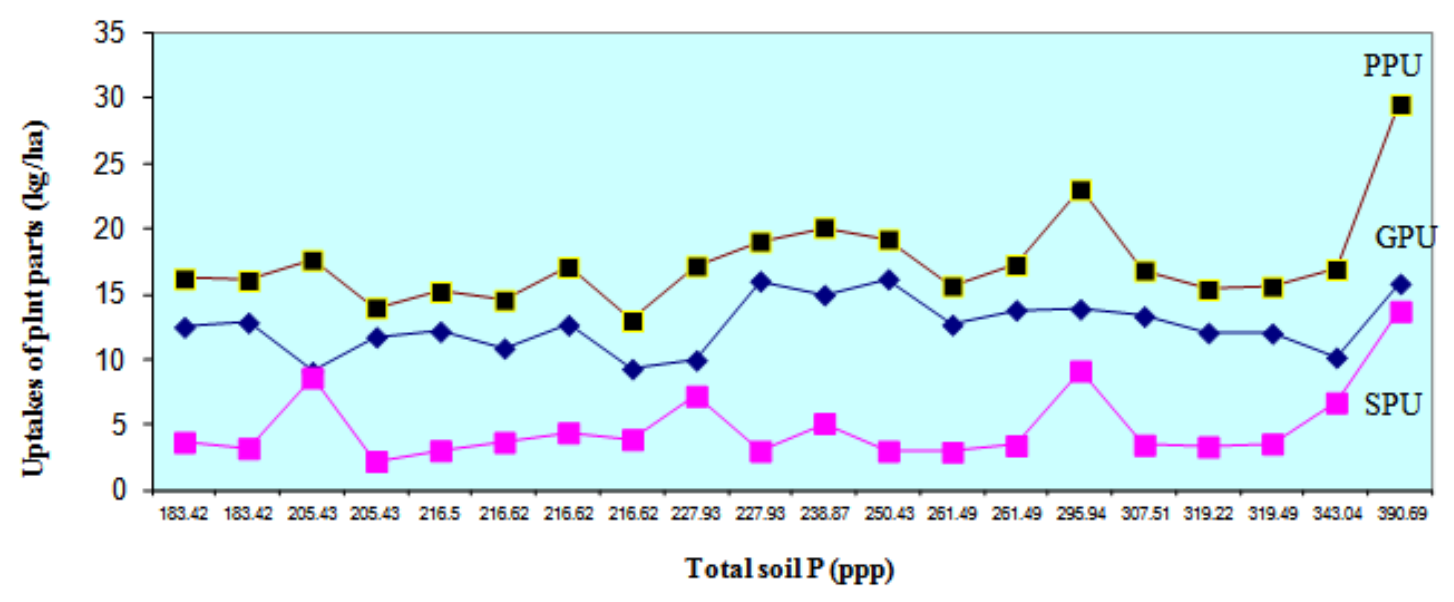

Figure 5. Functional relationship between total soil $P$ and $P$ uptakes in plant parts (grain, stover and whole maize plant. PPU - plant P uptake, GPU - grain P uptake, SPU - stover P uptake, and kg/ha - kilograms per hectare.

concentration in the grain parts of the maize crop with 11 and 14 percents of coefficient of determination, respectively. As illustrated in Figures 4 and 5, there is strong variability both within and among the three $P$ uptake parameters against the 20 labels of the incremental levels of available and total soil $P$, which was entailed due to the effect of the treatment interaction between $P$ placement methods and maize varieties. As shown in the line graphs drawn for each the three plant tissue uptake parameters, $\mathrm{P}$ uptake in grain, stover and total above ground parts showed up-and-down variability along the 20 labels of both available and total soil P. However, all of the three $P$ uptake parameters showed increased uptake efficiency at the highest labels of $P$ availability (Figure 4) and total soil $P$ (Figure 5). The unique feature observed in this experiment is that there is similar trend (Figures 4 and 5) and direct relationship $(r=$ $0.713^{\star \star}$ ) between available and total $P$ levels of the soil in contrast to Mnkeni et al. (1995) who concluded that total quantity of soil $P$ has little or no relationship to its availability. This might be because of the presence of enough reserve $P$ in the soil solution before fresh $P$ application. The freshly applied $\mathrm{P}$ seems to form several fractions of available $P$ in the soil in the form of pool of ions that can intern move to the roots to be absorbed by the plants during the period of growth.

\section{CONCLUSION}

The soil of the experimental field was found to be dark brown in color (when moist), clay loam in texture, and neutral ( $\mathrm{pH}: 6.9$ ) in reaction. With regard to nutrient status, the initial soil test values of both available and total $P$ increased due to PPD, RD and PPS and decreased due to the BC's $P$ placement methods and no $P$ treatment (NPP). Moreover, among placement methods, PPD and/or RD methods would be generally preferred to grow maize for $\mathrm{P}$ uptakes in grain, stover and total plant parts regardless of the genotypes used. In respect to genotype selection, the local cultivar out smarted in $P$ uptake of both the grain and stover plant parts, and as well as the whole plant $\mathrm{P}$ uptake. For instance, to harvest high $\mathrm{P}$ in stover as it might be needed for silage quality; the local 
cultivar still appeared to be the best as compared to all improved varieties. The interaction between the local cultivar and PPD was still advisable to be chosen for efficient uptake especially in the stover and the whole maize plant parts.

\section{REFERENCES}

Bieleski RL, Ferguson IB, 1983. Physiology and metabolism of phosphate and its compounds. Encyclopedia Plant Physiol, 15: 422449.

Fisseha I, 1982. Uptake and Response of Bread Wheat, Triticum Aestivum L. to $\mathrm{N}$ and P Fertilization of Arsi Neggele and Demberkella Soils in the Southern Rift Valley. Master of Science thesis presented to the School of Graduate Studies. Addis Ababa University, Ethiopia. $76 \mathrm{pp}$.

Food and Agricultural Organization (FAO), 2016. Soils and Pulses Symbiosis for Life. Rome, Italy.

Gomez AK, Gomez AA, 1984. Statistical Procedures for Agricultural Research $\left(2^{\text {nd }}\right.$ ed.). Wiley-Inter-science publication. John Wiley and Sons, Inc. $680 \mathrm{pp}$.

Ho CT, 1992. Results of Fertilizer Trials Conducted on Major Cereal Crops for 1988-91. Agricultural Development Department / National Fertilizer and Input Unit. Joint working paper №. 43. Addis Ababa, Ethiopia. 83pp.

Jensen ES, Hauggaard NH, 2003. How can increased use of biological N2 fixation in agriculture benefit the environment? Plant Soil, 252(1): 177-186.

Kipps MS, 1981. Production of Field Crops. A textbook of Agronomy (6 ${ }^{\text {th }}$ ed.). Mc Grow Hill publishing company Ltd, New Delhi. 790p.

Lu DQ, Chien SH, Henao J, Sompongse D, 1987. Evaluation of shortterm efficiency of di-ammonium phosphate versus urea plus single super phosphate on calcareous soil. Am Agron J, 79(5): 896-900.

Mallarino AP, Blackmer AM, 1992. Comparison of methods of determining critical concentrations of soil test phosphorus for corn. Am Agron J, 84(5): 850-856.

Mallarino AP, Bodoli JM, Borges R, 1999. Phosphorus and potassium placements effect on early growth and nutrient uptake of no-till corn and relationships with grain yield. Am Agron J, 91(1): 37-45.

Mesfin A, 1980. Soil science development for agriculture in Ethiopia. Ethiopian J Agric Sci, 2(2): 145-154.

Miller RW, Donahue RL, 1995. Soils in Our Environment $\left(7^{\text {th }} \mathrm{ed}\right)$. Prentice Hall Englewood Cliffs, New Jersey. 648 pp.

Mnkeni PN, Semoka JM, Makamba D, 1995. Bioavailable P status in some benchmark soils of Morogoro district, Tanzania. Norwegian $\mathrm{J}$ Agric Sci, 21: 108-115.

Olson RA, Sander DH, 1992. Corn Production. In: Corn and Corn Improvement ( $3^{\text {rd }}$ ed). Sprague, G.F. and Dudley, J.W. (eds.), pp. 664-672. Agronomy No. 8. American Society of Agronomy, United States of America.

Ouyang DS, Mackenzief AF, Fan MX, 1999. Availability of banded triple super phosphate with urea and phosphate use efficiency by corn. Literature Update Maize, 5(3):10.

Pablo AB, Hernán RS, Fernanda C, Hernán EE, 2014. Phosphorus Placement Effects on Phosphorous Recovery Efficiency and Grain Yield of Wheat under No-Tillage in the Humid Pampas of Argentina. Int J Agron, Article ID 507105, 12 pages.

Robert TL, 2008. Improving nutrient use efficiency. Turk J Agric, 32:177-182.

Taylor RW, Lindo PV, Shuford JW, Adriano DC, Sajwan KS, 1998. Availability to crops of residual $P$ from a sludge treated soil. Journal of Environmental Science and Health, Part A, 33(6): 1075-1090.

Tisdale SL, Nelson WL, Beaton JD, Hailin JL, 1993. Soil Fertility and Fertilizer ( $5^{\text {th }}$ ed.). Macmillan publishing company. $634 \mathrm{pp}$.
Citation: Tefera E, Gebrekidan H, 2017. Phosphorous use efficiency as affected by phosphorous placement methods and maize genotypes in Arsi Neggele, Ethiopia. Net J Agric Sci, 5(3): 94-104. 